\title{
HUBUNGAN PENGGUNAAN GIGI TIRUAN PENUH DENGAN STATUS GIZI PADA LANSIA DI DESA TONRONG RIJANG KECAMATAN BARANTI KABUPATEN SIDRAP
}

\section{The Relationship Between the Use Of Full Dentures and Nutritional Status In the Elderly Tonrong Rijang Baranti Sidrap}

\author{
Rusnaeni ${ }^{1}$, Muhammad Asikin ${ }^{2}$, Fitriani Umar ${ }^{3}$ \\ ${ }^{1)}$ Mahasiswa Konsentrasi Gizi Fakultas Ilmu Kesehatan Universitas Muhammadiyah Parepare \\ 2) Dosen Program Studi Kesehatan Masyarakat Universitas Muhammadiyah Parepare \\ ${ }^{3)}$ Dosen Program Studi Kesehatan Masyarakat Universitas Muhammadiyah Parepare \\ (rusnaenirusnaeni476@gmail.com)
}

\begin{abstract}
ABSTRAK
Salah satu perubahan secara biologis dapat mempengaruhi status gizi pada masa tua yaitu banyaknya gigi geligi yang sudah tanggal. Mengakibatkan gangguan fungsi mengunyah yang berdampak pada kurangnya asupan gizi pada usia lanjut, untuk memperbaiki mastikasi pengunyahaan maka lansia kebanyakn menggunaka gigi tiruan penuh. Penelitian ini bertujuan untuk mengetahui hubungan penggunaan gigi tiruan penuh dengan status gizi pada lansia di Desa Tonrong Rijang Kecamatan Baranti Kabupaten Sidrap.Jenis penelitian ini observasional analitik dengan rancangan cross sectional study. Populasi yaitu seluruh lansia yang tinggal menetap di Desa Tonrong Rijang, Pengambilan sampel dengan metode purposive sampling sebanyak 54 orang diperoleh dengan menggunakan rumus Slovin. Analisis data dengan menggunakan uji chi-square dan fisher exact test. dan $\mathrm{H}_{0}$ ditolak jika nilai $p<0,05$. Hasil penelitian diperoleh tidak ada hubungan penggunaan gigi tiruan penuh dengan asupan energi $(p=0,133)$ dan status gizi $(p=0,05)$, Serta ada hubungan signifikan asupan energi dengan status gizi $(p=0,000)$. Diharapkan kepada lansia untuk terus mempertahakan asupan energinya guna menigkatkan status gizi lansia untuk menunjang masa tuanya untuk hidup secara mandiri baik itu pengguna gigi tiruan penuh maupun yang tidak.
\end{abstract}

\section{Kata Kunci : Penggunaan Gigi Tiruan, Asupan Energi, Status Gizi, Lansia.}

\begin{abstract}
One of the biological changes can affect nutritional status in old age, namely the number of teeth that havebeen dated. Resulting in chewing function disorders that have an lmpacton the lack ofnutritional intake lnthe elderly, to improve mastication, the elderly mostly use full dentures. This study aimsto determine the relationship between the use of full denture with nutritional status in the elderly in Tonrong Rijang, Baranti, Sidrap.Thetype of this research is analytic observational with cross sectional study design. The population isall elderly people who live in the village of Tonrong Rijang, taking samples using purposive sampling method as many as 54 people obtained by using the Slovin formula. Data analysis using chi-square test and fisher exact test. $H_{0}$ is rejected if the value of $p>0.05$. The results of this researchshowed that there was no correlation between full denture use and energy intake $(p=0.133)$ and nutritional status $(p=0.05)$, and there was a significant correlation between energylntake and nutritional status $(p=0.000)$. it is expected that the elderly will continue to maintain their energy intake in order to improve the nutritional status of the elderly to support their old age to live independently both of full and non-nutritional use of nutrition.
\end{abstract}

Keywords: The Use of dentures, Energy Intake, Nutritional Status, Elderly. 


\section{PENDAHULUAN}

Lansia dikatakan sebagai tahap akhir perkembangan pada daur kehidupan manusia. Bertambahnya usia seseorang, maka penuaan pun tidak dapat dihindari. Menurut Undang-

Presentase penduduk lansia di Indonesia mengalami peningkatan cukup signifikan selama 30 tahun terakhir dengan populasi 5,3 juta (4,48\%) pada tahun 1971 menjadi 19,3 juta $(8,37 \%)$ pada tahun 2009. Peningkatan jumlah penduduk lansia ini disebabkan peningkatan angka harapan hidup sebagai dampak dari peningkatan kualitas kesehatan. Meningkatnya kualitas lansia tersebut harus diimbangi dengan peningkatan kualitas hidup lansia agar dapat hidup sehat, produktif, dan mandiri sehingga tidak menjadi beban bagi keluarga dan pemerintah serta dapat menjadi aset negara yang berharga dalam proses pembangunan. ${ }^{2}$

Masalah gizi yang terjadi pada lansia dapat berupa gizi kurang atau gizi lebih. Persentase penduduk lansia di Indonesia yang berada di perkotaan dalam keadaan kurang gizi adalah 3,4\% dan berat badan kurang 28,3\%, berat badan lebih $6,7 \%$, obesitas $3,4 \%$ dan berat badan ideal $42,4 \%$. Berdasarkan data tersebut, masalah gizi yang sering terjadi pada lansia adalah gizi kurang dan berat badan kurang. Hal ini terlihat dari persentase masalah gizi kurang dan berat badan kurang lebih besar dari pada masalah obesitas dan berat badan lebih pada lansia. ${ }^{3}$

Hasil penelitian yang dilakukan oleh Ira Hermawati (2017) jika dilihat dari segi usia
Undang Nomor 13 tahun 1998 pasal 1 ayat 2, yang dimaksud dengan lansia adalah seseorang yang telah mencapai usia 60 tahun ke atas. ${ }^{1}$

dan status gizi, kategori usia lansia tua (75-90 tahun) terdapat status gizi kurang sebesar $37,5 \%$, sedangkan kategori usia lansia (60-70 tahun) status gizi kurang sebesar 35,9\%. Hasil tersebut menandakan bahwa semakin tua usia seseorang resiko mengalami status gizi kurang semakin meningkat. ${ }^{4}$ Hal ini sesuai dengan yang dikemukakan oleh Fatimah, dimana ia menjelaskan bahwa seiring bertambahnya usia, kebutuhan zat gizi karbohidrat dan lemak juga menurun, sedangkan kebutuhan protein, vitamin dan mineral meningkat. Sehingga lansia yang umurnya lebih tinggi dapat memiliki resiko masalah gizi yang lebih besar, baik masalah status gizi kurang maupun gizi lebih. $^{5}$

Usia lanjut sering mempunyai masalah dalam hal makan, antara lain nafsu makan menurun. Padahal meskipun aktivitasnya menurun sejalan dengan bertambahnya usia. Ia tetap membutuhkan asupan zat gizi lengkap, seperti karbohidrat, protein, lemak, vitamin, dan mineral. Ia pun tetap masih membutuhkan energi untuk menjalankan fungsi fisiologis tubuhnya. Salah satu perubahan secara biologis dapat mempengaruhi status gizi pada masa tua yaitu banyaknya gigi geligi yang sudah tanggal. Mengakibatkan gangguan fungsi mengunyah yang berdampak pada kurangnya asupan gizi pada usia lanjut. Kehilangan gigi 
penyebab utama adalah periodental disease yang bisa terjadi setelah umur 30 tahun, penyebab lain meliputi kesehatan gigi yang buruk dan gizi yang buruk. ${ }^{6}$

Lansia adalah periode yang telah mencapai masa tua dalam ukuran fungsi dan juga telah menunjukan kemunduran sejalan dengan waktu. Lansia juga identik dengan menurunnya daya tahan tubuh dan mengalami berbagai macam penyakit. Pada keadaan lanjut usia biasanya terjadi penurunan tingkat kebersihan gigi dan mulut dan juga berkurangnya gigi geligi yang berakibat kehilangan gigi. ${ }^{7}$

Seiring bertambahnya usia, semakin besar pula kerentanan seseorang untuk kehilangan gigi. status kesehatan gigi dapat mempengaruhi status nutrisi seseorang. kehilangan banyak gigi akan sangat mempengaruhi fungsi pengunyahan seseorang, memberikan dampak negatif terhadap kesehatan umum dan menyebabkan terjadinya pembatasan diet tertentu dan asupan nutrisi yang sangat dibutuhkan tubuh. kehilangn gigi erat kaitannya dengan perubahan alam pemilihan makanan dan gangguan nutrisi pada lansia. $^{8}$

Indonesia memiliki permasalahan pada gigi dan mulut sebesar 25,9\%, prevalensi kehilangan gigi pada kelompok umur 55-64 tahun sebesar $10,13 \%$ dan pada usia $\geq 65$ tahun keatas sebesar 17,05\%. Penyebab utama kehilangan gigi lansia di Indonesia karies dan penyakit periodontal. ${ }^{7}$
Menurut data profil puskesmas Baranti tahun 2017, wilayah kerja puskesmas Baranti terdiri dari 2 kelurahan 4 desa, jumlah keseluruhan lansia yang ada di kecamatan Baranti sebanyak 4.290 Lansia. Adapun yang tinggal dan menetap di kelurahan Baranti sebanyak 1.073, di kelurahan Duampanua sebanyak 936, di desa Passeno sebanyak 787, di desa Sipodeceng sebanyak 833, di desa Tonronge sebanyak 343, di desa Tonrong Rijang sebanyak 318, lansia yang menggunakan gigi tiruan penuh sebanyak 215 lansia yang tinggal dan menetap di desa Tonrong Rijang. ${ }^{9}$ Penggunaan gigi tiruan penuh pada lansia bisa dikatakan lumayan banyak dilihat dari jumlah keseluruhan lansia yaitu 318 lansia yang menggunakan gigi tiruan sebanyak 215 , sementara lansia yang berumur $>60$ tahun sebanyak 121 lansia. Banyaknya keluhan dari masyarakat khususnya pada lansia mengenai rasa sakit, sulit mengunyah, membatasi mengkonsumsi makanan tertentu akibat kehilangan gigi yang juga berdampak pada status gizi lansia, dari keluhan dan masalah tersebut diatas sehingga peneliti tertarik untuk meneliti hubungan penggunaan gigi tiruan penuh dengan status gizi pada lansia di desa Tonrong Rijang Kecamatan Baranti Kabupaten Sidrap.

\section{BAHAN DAN METODE PENELITIAN}

Jenis penelitian ini observasional analitik dengan rancangan cross sectional study. Dilaksanakan di Desa Tonrong Rijang Kecamatan Baranti Kabaupaten Sidrap di 
mulai pada tanggal 17 Mei samapi 27 Juni 2018 .Populasi yaitu seluruh lansia yang tinggal menetap di Desa Tonrong Rijang, Pengambilan sampel dengan metode purposive sampling sebanyak 54 orang diperoleh dengan menggunakan rumus Slovin.

\section{HASIL PENELITIAN}

Berdasarkan distribusi karakteristik responden berdasarkan usia, jenis kelamin tingkat pendidikan dan pekerjaan pada tabel 3 menunjukkan bahwa usia sampel terbanyak berada pada kategori usia $\geq 70$ tahun yaitu 27 lansia $(50,0 \%)$ dan yang paling sedikit adalah kategori usia 60-64 yaitu 12 lansia (22,2\%). Berdasarkan jenis kelamin, responden perempuan memiliki jumlah lebih banyak yaitu 34 lansia $(63,0 \%)$ dibanding responden lakilaki yaitu 20 lansia (37,0\%). Karakteristik responden berdasarkan tingkat pendidikan, sebagian besar responden yang berpendidikan Sekolah Dasar yaitu sebanyak 31 lansia $(57,4 \%)$, Sedangkan yang tidak tamat SD sebanyak 20 lansia (37,0\%). dan sebagian kecil tingkat Pendidikan SMP yaitu sebanyak 3 lansia (5,6\%). Karakteristik responden berdasarkan pekerjaan sebagian besar sampel yang pekerjaan IRT/Tidak kerja yaitu 36 lansia $(66,7 \%)$, sedangkan yang bekerja sebagai petani yaitu 18 lansia $(33,3 \%)$.

Berdasarkan distribusi penggunaan gigi tiruan penuh pada lansia pada tabel 4 juga menunjukkan karakteristik responden berdasarkan penggunaan gigi tiruan penuh. Responden yang menggunakan gigi tiruan penuh sebanyak 37 lansia $(68,5 \%)$ dan lansia yang tidak menggunakan gigi tiruan penuh sebanyak 17 lansia (31,5\%). Lama penggunaan gigi tiruan penuh oleh lansia sebagian besar ialah lebih dari $\geq 6$ tahun sebanyak 29 lansia $(63,7 \%)$ sedangkan penggunaan gigi tiruan penuh yang kurang dari 2-6 tahun sebanyak 7 lansia $(13,0 \%)$. Dan paling kecil lama penggunaan gigi tiruan penuh yang kurang dari 1 tahun sebanyak 1 lansia $(1,9 \%)$.

Karakteristikresponden berdasarkan penyakit sistemik pada tabel 4 , sebagian besar lansia tidak mengalami penyakit sistemik yaitu sebanyak 48 lansia $(88,9 \%)$ dan sebagian kecil mengalami penyakit sistemik hanya 6 lansia $(11,1 \%)$, adapun penyakit sistemik yang dialami oleh responden seperti hipertensi, diabetes melitus, penyakit jantung. Karakteristik responden berdasarkan yang merokok, sebagian besar lansia tidak merokok yaitu sebanyak 53 lansia $(98,1 \%)$ sementara yang merokok hanya sebanyak 1 lansia $(1,9 \%)$.

Berdasarkan distribusi satatus gizi dan asupan energi lansia pada tabel 5 menunjukkan karakteristik responden berdasarkan status gizi. Sebagian besar lansia memiliki status gizi normal sebesar 39 lansia $(72,2 \%)$ dan yang status gizi kurus sebesar 15 lansia $(27,8 \%)$. Berdasarkan karakteristik asupan energi sebagian besar lansia kategori cukup yaitu 34 lansia $(63,0 \%)$ dan sebagian kecil kategori kurang yaitu 20 lansia $(37,0 \%)$.

Berdasarkan hubungan penggunaan gigi tiruan penuh dengan asupan energi pada tabel 6 menunjukkan bahwa asupan energi dengan kategori cukup lebih banyak pada 
lansia pengguna gigi tiruan penuh $(70,3 \%)$ dibanding pada lansia tidak menggunkan gigi tiruan penuh $(47.1 \%)$. Namun masih terdapat asupan energi kurang pada pengguna gigi tiruan penuh yaitu $(29,7 \%)$ sementara asupan energi kategori kurang yang tidak menggunakan gigi tiruan penuh yaitu $(52,9)$ Berdasarkan analisis Chi Square diperoleh nilai $p=0,133>\alpha(0,05)$ yang menunjukkan bahwa tidak ada hubungan penggunaan gigi tiruan penuh dengan asupan energi lansia.

Berdasarkan hubungan penggunaan gigi tiruan penuh dengan status gizi pada tabel 7 menunjukkan bahwa status gizi dengan kategori normal lebih banyak pada lansia pengguna gigi tiruan penuh $(81,1 \%)$ dibanding pada lansia tidak menggunkan gigi tiruan penuh $(52,9 \%)$. Sedangkan untuk kategori kurus lebih besar pada lansia tidak menggunakan gigi tiruan penuh $(47,1 \%)$ dibandingkan yang menggunakan gigi tiruan penuh $(18,9 \%)$ Berdasarkan analisis fisher exact test dengan nilai $p=0,050 \geq \alpha(0,05)$ yang menunjukkan bahwa tidak ada hubungan penggunaan gigi tiruan penuh dengan status gizi lansia.

Berdasarkan hubungan asupan energi dengan status gizi pada tabel 8 menunjukkan bahwa lansia yang memiliki status gizi kurus lebih banyak yang asupan energinya kurang (75\%) sedangkan yang status gizi normal (100\%) memiliki asupan energi cukup. Berdasarkan analisis Chi Square diperoleh nilai $p=0,000<\alpha(0,05)$ yang menunjukkan bahwa ada hubungan penggunaan gigi tiruan penuh dengan asupan energi lansia.

\section{PEMBAHASAN}

Pada penelitian yang telah dilakukan, mayoritas sampel penelitian ada pada kelompok usia $\geq 70$ tahun sebanyak 27 lansia atau 50,0\% hasil tersebut menunjukkan bahwa usia harapan hidup lansia di desa Tonrong Rijang berada pada rentang usia $\geq 70$ tahun. Hal tersebut sesuai dengan usia harapan hidup di Indonesia yaitu 72 tahun. Seiring bertambahnya usia, maka bertambah pula penurunan fungsi tubuh. Semakin menurunnya daya tahan fisik, seperti semakin rentannya seseorang terhadap serangan penyakit yang dapat menyebabkan kematian. Hal ini disebabkan terjadinya perubahan dalam struktur dan fungsi sel, jaringan, dan sistem organ. Lansia yang rawan terhadap gizi kurang, respon kekebalan tubuhnya buruk, lebih muda terserang infeksi, dan komplikasi penyakit yang akan meningkatkan risiko kematian. ${ }^{10}$

Terlihat pula bahwa kebanyakan responden penelitian berjenis kelamin perempuan yaitu sebanyak 34 lansia $(63,0 \%)$ sedangkan responden laki-laki sebanyak 20 lansia $(37,0 \%)$. Hasil tersebut menunjukkan bahwa usia harapan hidup perempuan lebih tinggi dibanding laki-laki. Hal tersebut sesuai dengan gambaran kesehatan lanjut usia di Indonesia yang mengatakan usia harapan hidup di Indonesiaialah 72 tahun yang mana usia harapan hidup perempuan (74 tahun) lebih 
tinggi daripada laki-laki (68 tahun). ${ }^{11}$ Selain itu, sampel perempuan yang lebih banyak dari sampel laki-laki dapat disebabkan oleh karena sebagian besar perempuan lebih memilih menetap di rumah sebagai ibu rumah tangga daripada bekerja di luar. Sedangkan sampel laki-laki sebagian besar memilih bekerja diluar. Sehingga, sampel yang ditemui di lokasi penelitian sebagian besar berjenis kelamin perempuan.

Penelitian ini dilakukan pada 54 lansia yaitu 37 lansia pengguna gigi tiruan penuh dan 17 lansia bukan pengguna gigi tiruan penuh dengan sebagian besar pendidikan terakhirnya ialah SD sebanyak 31 lansia (57,4\%). Banyaknya lansia yang pendidikan terakhirnya hanya sampai sekolah dasar dan bahkan tidak tamat sekolah dasar akan mempengaruhi tingkat pengetahuan terhadap pentingnya menjaga kesehatan gigi dan mulut, khususnya penggunaan gigi tiruan penuh pada lansia.

Hasil penelitian ini menujukkan bahwa asupan energi sebagian besar lansia kategori cukup yaitu 34 lansia $(63,0 \%)$ dengan status gizi normal sebesar 39 lansia (72,2\%). Hal tersebut menunjukkan bahwa lansia yang asupan energinya cukup akan mempengaruhi status gizi lansia hal ini disebakan semakin banyak jumlah asupan energi yang masuk kedalam tubuh lansia maka akan meningkatkan status gizi pada lansia.

Hubungan penggunaan gigi tiruan penuh dengan asupan energi lansia terlihat pada lansia pengguna gigi tiruan penuh memiliki asupan energi yang cukup (70,3\%) lebih banyak daripada lansia bukan pengguna gigi tiruan penuh $(47,1 \%)$. Sedangkan lansia yang asupan energinya kurang lebih kecil pada lansia menggunakan gigi tiruan penuh $(29,7 \%)$ dibanding dengan lansia tidak menggunakan gigi tiruan penuh $(52,9 \%)$. Hal tersebut menunjukkan tidak ada hubungan antara penggunaan gigi tiruan penuh dengan asupan energi pada lansia secara keseluruhan. Hal ini disebabkan karena pada pengguna gigi tiruan penuh masih terdapat lansia yang asupan energinya masih kurang dibanding dengan lansia yang tidak menggunakan gigi tiruan penuh itu masih ada.

Lansia bukan pengguna gigi tiruan penuh cenderung mengubah makanan mereka dari yang keras menjadi lunak untuk mengurangi proses pengunyahan atau takut tersedak. Hal ini akan menurunkan fungsi pengunyahan (mastikasi) yang akan berpengaruh pada pemilihan makanan dari yang segar dan berserat menjadi yang dimasak dalam waktu lama yang akan mengurangi kandungan nutrisi pada makanan tersebut. Proses pengunyahan merupakan proses yang meliputi aktivitas fasial, mandibula, otot suprahyoid, dan lidah yang berfungsi untuk menggilas makanan yang akan masuk ke tahap pencernaan selanjutnya. ${ }^{12}$ Sehingga penggunaan gigi tiruan penuh pada lansia yang edentulous (kehilangan gigi) akan memperbaiki sistem stomatognatik, khususnya dalam proses mastikasi (pengunyahan) sehingga asupan makanan menjadi lebih baik dan gizinya pun menjadi meningkat. 
Hasil tersebut tidak sesuai dengan penelitian yang dilakukan Prakash $\mathrm{N}$ dkk yang mengatakan bahwa rehabilitasi prostetik pada pasien edentulous (kehilangan gigi) dengan penggunaan gigi tiruan penuh akan meningkatkan asupan pasien tersebut. Hal tersebut disebabkan oleh karena kesehatan rongga mulut, khususnya banyaknya gigi yang tersisa, akan berefek pada kemampuan mastikasi dan nafsu makan. Status gigi akan mempengaruhi pemilihan makanan, status nutrisi dan kesehatan secara umum. Kemampuan mastikasi yang menurun akan berkaitan dengan menurunnya kapasitas fungsional dan kesehatan umum. Sehingga, rehabilitasi prostetik pada pasien edentulous dengan penggunaan gigi tiruan penuh akan meningkatkan asupan nutrisinya, begitupula sebaliknya. Lansia yang edentulous tanpa penggunaan gigi tiruan berisiko lebih tinggi pada asupan nutrisi rendah. ${ }^{13}$

Hal tersebut dapat disebabkan karena status gizi dipengaruhi oleh asupan nutrisi seseorang. Apabila terjadi gangguan pada proses pencernaan, maka asupan nutrisipun akan terganggu. Adanya gangguan pada sistem stomatognatik dapat menyebabkan ketidakseimbangan nutrisi. Sehingga, kehilangan gigi merupakan salah satu faktor yang dapat mempengaruhi intek makanan.

Pada penelitian ini tidak ada hubungan penggunaan gigi tiruan penuh dengan status gizi terlihat bahwa status gizi kurus $(\leq 18,5$ $\mathrm{kg} / \mathrm{m}^{2}$ ) lebih banyak pada lansia tidak menggunakan gigi tiruan penuh $(47,1 \%)$ namun terlihat pula bahwa status gizi kurus $\left(\leq 18,5 \mathrm{~kg} / \mathrm{m}^{2}\right)$ pada lansia pengguna gigi tiruan penuh $(18,9 \%)$. Sedangkan status gizi normal $\left(\geq 18,5 \mathrm{~kg} / \mathrm{m}^{2}\right)$ lebih banyak pada lansia pengguna gigi tiruan penuh $(81,1 \%)$ dibanding tidak menggunakan gigi tiruan penuh $(52,9 \%)$. Dan untuk status gizi lainnya tidak memiliki perbedaan yang cukup berarti memperlihatkan bahwa tidak ada hubungan antara penggunaan gigi tiruan penuh dengan status gizi lansia. Sehingga lansia yang menggunakan gigi tiruan penuh memiliki status gizi yang lebih tinggi dibanding lansia yang tidak menggunakan gigi tiruan.

Dalam penelitian ini, lansia dengan kategori status gizi kurus dapat di sebabkan karena pada usia lanjut terjadi perubahan fisik pada sistem gastrointestinal yaitu kehilangan gigi akibat periodontal disease (kerusakan pada gigi) yang biasanya terjadi setelah umur 30 tahun. ${ }^{14}$ Pemakaian gigi tiruan penuh juga tidak menjamin perbaikan fungsi mastikasi karena sering gigi tiruan rahang bawah terlalu menekan jaringan di bawahnya gigi tiruan yang tidak stabil, dan iritasi gigi tiruan yang menyebakan rasa nyeri. Gigi tiruan yang diharapkan dapat memperbaiki atau mendukung fungsi mastikasi yang sudah berkurang pada lansia dan meningkatkan status gizinya, akan tetapi terkadang dengan adanya gigi tiruan baru belum dapat memperbaiki status gizi lansia akibat berbagai kondisi yan seperti nyeri akibat gigi tiruan rahang bawah terlalu menekan jaringan dibawahnya sehingga seseorang harus cermat untuk membuat 
makanan tersebut dapat dikonsumsi oleh lansia. ${ }^{15}$

Hasil penelitian ini juga menunjukkan bahwa status gizi kurang disebabkan karena adanya riwayat penyakit sistemik penyakit yang terjadi pada responden seperti diabetes melitus, hipertensi, penyakit ginjal, penyakit jantung. seperti yang terlihat dimana responden yang menggunakan gigi tiruan penuh terdapat 6 lansia $(11,1 \%)$. Masalah gizi kurang pada lanjut usia dapat disebabkan oleh beberapa faktor diantaranya riwayat penyakit, kondisi atau perawatan mulut, asupan makanan dan kebiasaan merokok. Gangguan fungsional memiliki hubungan yang kuat dengan kekurangan nutrisi, dan kesulitan memperoleh makanan. Kondisi rongga mulut dan perawatan mulut yang tidak adekuat dapat mempengaruhi status gizi seseorang. Perawatan mulut yang tidak adekuat biasanya menjadi penyebab masalah kesehatan mulut yang dapat mengakibatkan kekurangan nutrisi dan berpengaruh pada sistem pencernaan. ${ }^{3}$

Penelitian ini sejalan dengan hasil penelitian Melia tahun 2014 yang menyatakan bahwa tidak ada hubungan bermakna antara variabel pemakaian gigi tiruan dengan status gizi dengan nilai $(\mathrm{p}=0,252)$. Pengguna gigi tiruan penuh pada penelitiannya hanya terdapat satu responden yang menggunakan gigi tiruan dari 75 responden yang di teliti yang mengakibatkan berefek pada analisi data ${ }^{16}$. Dibandingkan dengan hasil penelitian ini responden yang menggunakan gigi tiruan penuh sebanyak 37 responden dari 54 responden, namun masih terdapat responden yang status gizinya kurang akibat penyakit sistemik yang di derita oleh responden yang akan mempengaruhi status gizi meskipun telah menggunakan gigi tiruan penuh.

Hubungan status gizi dengan asupan energi lansia terlihat pada lansia yang status gizinya kategori normal memiliki asupan energi yang cukup $(100,0 \%)$ lebih banyak daripada lansia bukan yang status gizinya kurus $(0.0 \%)$. Sedangkan lansia yang asupan energinya kurang lebih banyak pada lansia yang status gizinya kategori kurus $(75,0 \%)$ dibanding dengan lansia yang asupan energinya kurang dengan status gizi kaegori kurang $(25,0 \%)$. Hal tersebut menunjukkan ada hubungan antara penggunaan gigi tiruan penuh dengan asupan energi pada lansia secara keseluruhan. Hasil penelitian ini sejalan dengan hasil penelitian yang dilakukan oleh Susilawati menyatakan bahwa ada hubungan antara pola konsumsi dengan status gizi pada lansia di desa Culik $(p=0,00)$. Masalah kesehatan gigi dan mulut merupakan bagian dari status kesehatan yang berperan dalam perubahan status gizi. Kondisi inilah yang dapat mengubah cara makan sehingga mempersulit asupan zat gizi. ${ }^{17}$

Hasil penelitian yang dilakukakan oleh Dewi Ari dkk (2013) terdapat hubungan yang bermakna antara asupan energi dan asupan protein dengan status gizi lansia di wilayah kerja UPT Kesmas Blahbatuh II Gianyar.Berdasarkan analisis menggunakan metode One-way ANOVA didapatkan taraf 
signifikansi untuk nilai means yang mewakili angka kecukupan energi lansia didapatkan angka $p=0,017$.

Status gizi lansia dapat dipengaruhi oleh pola konsumsi energi dan protein, faktor status kesehatan, pengetahuan, ekonomi, lingkungan dan budaya. Faktor pencetus munculnya masalah gizi dapat berbeda antar wilayah ataupun antar kelompok masyarakat. Namun terdapat penelitian yang menerangkan bahwa tidak terdapat hubungan yang bermakna antara asupan energi dan protein dengan status gizi dari nilai $p=0.653(p>0.05) .{ }^{1}$ Padahal pola asupan protein dan energi dari makanan yang dimakan seharusnya berpengaruh terhadap status gizi seseorang. Lansia yang status gizinya menurun lebih mudah terserang penyakit. Penyakit yang muncul sering melibatkan sistem kekebalan tubuh yang seharusnya memadai. Sistem kekebalan sendiri membutuhkan protein sebagai bahan pokok pembentuk barrier adaptif di dalam tubuh lansia. ${ }^{18}$

\section{KESIMPULAN DAN SARAN}

Hasil penelitian menunjukkan tidak ada hubungan antara penggunaan gigi tiruan penuh

\section{DAFTAR PUSTAKA}

1. Undang-Undang Nomor 13 Tahun 1998. [online]. Available from: http://www.dpr.go.id/uu/uu1998/UU 1998 13.pdf. [diakses 20 November 2017]. dengan asupan energi pada lansia, tidak ada hubungan penggunaan gigi tiruan penuh dengan status gizi lansia, serta ada hubungan asupan gizi dengan status gizi pada lansia di desa Tonrong Rijang kecamatan Baranti kabupaten Sidrap $(p=0,000)$. Dari hasil penelitian, diharapkan pengguna gigi tiruan agar kiranya menjaga kesehatannya dan untuk bukan pengguna gigi tiruan penuh agar kiranya meningkatkan asupan energinya memperhatikan pola makan, pengolahan makanan agar nutrisi yang terkandung dalam makanan tidak berkurang untuk memenuhi kebutuhan nutrisi di dalam tubuh guna memeperbaiki status gizi lansia. Selain itu lansia harus mempertahankan asupan energinya guna meningkatkan status gizi lansia untuk menunjang masa tuanya untuk hidup secara mandiri. Perlu dilakukan penelitian selanjutnya mengenai hubungan status gizi dengan asupan energi pada lansia, baik pengguna maupun bukan pengguna gigi tiruan penuh dengan mengukur status gizi bukan hanya menggunakan IMT untuk menentukan status gizi tetapi juga menggunakan metode yang lain agar mendapat hasil yang lebih akurat.

2. Komisi Nasional Lanjut Usia. Profil Penduduk Lanjut Usia 2009. Jakarta;2010.

3. Wijayanti. 2008. Hubungan kondisi RTT lansia terhadap kondisi sosial lansia. [Jurnal Ilmiah Perancang Kota dan Permukiman] 7(1): 38,42. 
4. Hermawati Ira. 2017. Hubungan Kehilangan Gigi dengan Statsu Gizi Lansia di PSTW BUDI Mulia 03 Maraguna Jakarta Selatan [skripsi]. UIN Syari Hidayatullah Jakarta.

5. Fatmah. 2010. Gizi Usia Lanjut. Jakarta: Erlangga

6. Merryana A. W Bambang W. 2014. Peranan Gizi dalam Siklus Kehidupan. Jakarta: Kencana.

7. Ketut SW. 2015. Faktor - faktor yang Mempengaruhi Status Gizi pada Lansia [online] http://www.academia.edu/20080640/faktor faktor yang mempengaruhi status gizi pada lansia jurnal(diakses pada tanggal 21 maret 2018)

8. Nurfantir, Dian Y, 2016. Identifikasi Status Nutrisi dan Resiko Malnutrisi pada Lanjut Usia di Panti Sosial Tresna Werdha Minaula Kendari[jurnal] vol.4 No.2.

9. Data Profil Puskesmas Baranti. 2017. Data Program Usila.

10. Nur HA, dkk. 2013. Nutrisi pada Pengguna Gigi Tiruan Penuh [jurnal] Vol (12) No.1.

11. Padila. 2013. Buku Ajaran Keperawatan Gerontik. Yogyakarta: Nuha Medika; hal 410

12. Eric J, dkk. 2012.Validity and Reliability of The Oral Impacts on Daily Performance (OIDP) Scale in The Elderly Population Of
Bosnia And Herzegovina. Gerodontology; 29:902-8.

13. Khumairah Nur Ramadhani. 2014. Hubungan Penggunaan Gigi Tiruan Penuh dengan Status Gizi dan Kualitas Hidup Pada Lansia di Kota Makassar [Skripsi]. Universitas Hasanuddin Makassar.

14. Darmojo, B. 2011. Buku Ajar Geriatri Ilmu Kesehatan Lanjut Usia. FK UI : Jakarta

15. Dewi AW, dkk. 2013. Hubungan Antara Asupan Energi, Asupan Protein dan Aktivitas Fisik Terhadap Status Gizi Penduduk Lanjut Usia di Wilayah Kerja Upt Kesmas Blahbatuh Ii, Kecamatan Blahbatuh, Kabupaten Gianyar. Universitas Udayana.

16. Melia dkk. 2014. Hubungan Kehilangan gigi dan pemakainan Gigi Tiruan terhadap Status Gizi. Fakultas Kedokteran Gigi.Universitas Indonesia. Jakarta.

17. Akmal, Hilda F. 2012. Perbedaan Asupan Energi, Protein, Aktivitas Fisik dan Status Gizi Antara Lansia Yang Mengikuti dan Tidak Mengikuti Senam Bugar Lansia. Semarang: FK UNDIP.

18. [DEPKES RI] Departemen Kesehatan Republik Indonesia. 2005. Pedoman Pembinaan Kesehatan Usia Lanjut Bagi Petugas Kesehatan. Jakarta: Departemen Kesehatan RI. 


\section{LAMPIRAN}

Tabel 3. Distribusi Karakteristik Responden Berdasarkan Usia, Jenis Kelamin Tingkat Pendidikan dan Pekerjaan di Desa Tonrong Rijang Kecamatan Baranti Kabupaten Sidrap

\begin{tabular}{lcc}
\hline Karakteristik & n & Presentase (\%) \\
\hline Usia ( tahun) & & \\
$60-64$ & 12 & 22,2 \\
$65-69$ & 15 & 27,8 \\
$\geq 70$ & 27 & 50,0 \\
\hline Jenis kelamin & & \\
$\quad$ Laki-laki & 20 & 37,0 \\
$\quad$ Perempuan & 34 & 63,0 \\
\hline Tingkat Pendidikan & & \\
Tidak tamat SD & 20 & 37,0 \\
SD & 31 & 57,4 \\
SMP & 3 & 5,6 \\
\hline Pekerjaan & & \\
Petani & 18 & 33,3 \\
IRT/Tidak kerja & 36 & 66,7 \\
\hline Total & $\mathbf{5 4}$ & $\mathbf{1 0 0 , 0}$ \\
\hline
\end{tabular}

Tabel 4. Distribusi Responden Berdasarkan Penggunaan Gigi Tiruan Penuh pada Lansia di Desa Tonrong Rijang Kecamatan Baranti Kabupaten Sidrap

\begin{tabular}{|c|c|c|}
\hline Karakteristik & $\mathbf{n}$ & Presentase (\%) \\
\hline \multicolumn{3}{|l|}{ Gangguan mengunyah } \\
\hline $\mathrm{Ya}$ & 17 & 31,5 \\
\hline Tidak & 37 & 68,5 \\
\hline \multicolumn{3}{|l|}{ Menggunakan gigi tiruan penuh } \\
\hline 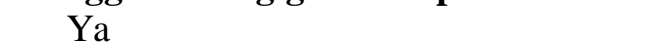 & 37 & 68,5 \\
\hline Tidak & 17 & 31,5 \\
\hline \multicolumn{3}{|c|}{ Lama Penggunaan gigi tiruan penuh (Tahun) } \\
\hline$\leq 1$ & 1 & 1,9 \\
\hline $2-6$ & 7 & 13,0 \\
\hline$\geq 6$ & 29 & 53,7 \\
\hline Tidak menggunakan gigi tiruan penuh & 17 & 31,5 \\
\hline \multicolumn{3}{|l|}{ Penyakit Sistemik } \\
\hline Ya & 6 & 11,1 \\
\hline Tidak & 48 & 88,9 \\
\hline \multicolumn{3}{|l|}{ Merokok } \\
\hline $\mathrm{Ya}$ & 1 & 1,9 \\
\hline Tidak & 53 & 98,1 \\
\hline Total & 54 & 100,0 \\
\hline
\end{tabular}


Tabel 5. Distribusi Status Gizi dan Asupan Energi Lansia di Desa Tonrong Rijang Kecamatan Baranti Kabupaten Sidrap

\begin{tabular}{lcc}
\hline Variabel & n & Presentase (\%) \\
\hline Status Gizi & & \\
$\quad$ Kurus & 15 & 27,8 \\
$\quad$ Normal & 39 & 72,2 \\
\hline Asupan Energi & & \\
$\quad$ Kurang & 20 & 37,0 \\
$\quad$ Cukup & 34 & 63,0 \\
\hline Total & $\mathbf{5 4}$ & $\mathbf{1 0 0 , 0}$ \\
\hline
\end{tabular}

Tabel 6. Hubungan Penggunaan Gigi Tiruan Penuh dengan Asupan Energi Lansia di Desa Tonrong Rijang Kecamatan Baranti Kabupaten Sidrap

\begin{tabular}{lccccccc}
\hline \multirow{2}{*}{$\begin{array}{l}\text { Menggunakan Gigi } \\
\text { Tiruan Penuh }\end{array}$} & \multicolumn{4}{c}{ Asupan Energi } & \multicolumn{2}{c}{ Total } & \multirow{2}{*}{$\boldsymbol{p}$} \\
\cline { 2 - 6 } & \multicolumn{2}{c}{ Kurang } & \multicolumn{2}{c}{ Cukup } & & \\
\cline { 2 - 7 } & $\mathbf{n}$ & $\mathbf{\%}$ & $\mathbf{n}$ & $\mathbf{\%}$ & $\mathbf{n}$ & $\mathbf{\%}$ & \\
\hline Tidak & 9 & 52,9 & 8 & 47,1 & 17 & 100,0 & \\
Ya & 11 & 29,7 & 26 & 70,3 & 37 & 100,0 & 0,133 \\
\hline Total & $\mathbf{2 0}$ & $\mathbf{3 7 , 0}$ & $\mathbf{3 4}$ & $\mathbf{6 3 , 0}$ & $\mathbf{5 4}$ & $\mathbf{1 0 0 , 0}$ & \\
\hline
\end{tabular}

Tabel 7. Hubungan Penggunaan Gigi Tiruan Penuh dengan Status Gizi pada Lansia di Desa Tonrong Rijang Kecamatan Baranti Kabupaten Sidrap

\begin{tabular}{|c|c|c|c|c|c|c|c|}
\hline \multirow{4}{*}{$\begin{array}{l}\text { Menggunaan Gigi } \\
\text { Tiruan Penuh }\end{array}$} & \multicolumn{3}{|c|}{ Status Gizi } & \multirow{2}{*}{\multicolumn{3}{|c|}{ Total }} & \multirow[b]{3}{*}{$P$} \\
\hline & & & & & & & \\
\hline & \multirow{2}{*}{$\frac{\text { Kurus }}{\mathbf{n}}$} & \multicolumn{2}{|c|}{ Normal } & \multirow[b]{2}{*}{$\%$} & \multirow[b]{2}{*}{$\mathbf{n}$} & \multirow[b]{2}{*}{$\%$} & \\
\hline & & $\%$ & $\mathbf{n}$ & & & & \\
\hline \multirow[t]{2}{*}{ Tidak } & 8 & 47,1 & 9 & 52,9 & 17 & 100,0 & \\
\hline & & & & & & & 0,050 \\
\hline $\mathrm{Ya}$ & 7 & 18,9 & 30 & 81,1 & 37 & 100,0 & \\
\hline Total & 15 & 27,8 & 39 & 72,2 & 54 & 100,0 & \\
\hline
\end{tabular}

Tabel 8. Hubungan Asupan Energi dengan Status Gizi pada Lansia di Desa Tonrong Rijang kecamatan Baranti kabupaten Sidrap

\begin{tabular}{cccccccc}
\hline \multirow{2}{*}{$\begin{array}{c}\text { Asupan } \\
\text { Energi }\end{array}$} & \multicolumn{9}{c}{ Status gizi } & \multicolumn{2}{c}{ Total } & \multirow{2}{*}{$\boldsymbol{p}$} \\
\cline { 2 - 6 } & \multicolumn{2}{c}{ Kurus } & \multicolumn{2}{c}{ Normal } & & & \multirow{2}{*}{ n } \\
\cline { 2 - 7 } & $\mathbf{n}$ & $\mathbf{\%}$ & $\mathbf{n}$ & $\mathbf{\%}$ & $\mathbf{n}$ & $\mathbf{\%}$ & \\
\hline Kurang & 15 & 75,0 & 5 & 25,0 & 20 & 100,0 & \\
Cukup & 0 & 0 & 34 & 100,0 & 34 & 100,0 & 0,000 \\
\hline Total & $\mathbf{1 5}$ & $\mathbf{2 7 , 8}$ & $\mathbf{3 9}$ & $\mathbf{7 2 , 2 , 0}$ & $\mathbf{5 4}$ & $\mathbf{1 0 0 , 0}$ & \\
\hline
\end{tabular}

